\title{
PENGARUH LINGKUNGAN KERJA DAN KEPEMIMPINAN TERHADAP KINERJA PETANI DI CAHAYA AGRIBIZ KECAMATAN PAGELARAN KABUPATEN CIANJUR
}

\author{
Oleh : \\ Nurjaya \\ Dosen Fakultas Sains Terapan UNSUR \\ nurjaya58023@gmail.com
}

\begin{abstract}
Abstrak
Tujuan penelitian ini adalah untuk mengkaji pengaruh lingkungan kerja dan kepemimpinan terhadap kinerja Petani pada Cahaya Agribiz Pagelaran Kabupaten Cianjur . Metode penelitian yang digunakan adalah metode deskriptif dan asosiatif. Pada penelitian ini menggunakan data primer dengan melakukan observasi serta menyebarkan kuesioner kepada responden. Seluruh populasi dijadikan obyek penelitian sehingga sampel dalam penelitian ini sebanyak 24 orang Petani Variabel independent dalam penelitian ini adalah lingkungan kerja (X1), kepemimpinan (X2) sedangkan variabel dependen adalah kinerja Petani (Y). Statistik uji hipotesis yang digunakan adalah Spearman Rank. Hasil penelitian ini adalah sebagai berikut bahwa secara umum lingkungan kerja yang ada di Cahaya Agribiz Pagelaran Kabupaten Cianjur telah dinilai baik oleh responden dengan rata-rata tingkat pencapaian sebesar $73.03 \%$, sedangkan kepemimpinan pada Cahaya Agribiz Pagelaran Kabupaten Cianjur dirasakan baik hal ini ditunjukkan rata-rata tingkat pencapaian sebesar $79.79 \%$, dan secara umum kinerja Petani pada Cahaya Agribiz Pagelaran Kabupaten Cianjur memiliki rata-rata tingkat pencapaian sebesar $81.15 \%$. Pengaruh antara lingkungan kerja dan kepemimpinan terhadap kinerja Petani ditunjukkan dengan derajat hubungannya sebesar 0.641, yang berada pada rentang antara 0,51-0,75 menunjukkan hubungan yang "Cukup kuat". Artinya bahwa Pengaruh lingkungan kerja dan kepemimpinan secara bersama-sama dapat meningkatkan kinerja Petani pada Cahaya Agribiz Pagelaran Kabupaten Cianjur dan hal ini menunjukkan nilai keeratan hubungan tersebut positif $(+)$. Sedangkan besarnya Pengaruh lingkungan kerja dan kepemimpinan terhadap kinerja Petani sebesar $45.90 \%$ (Koefisien Determinasi) dan sisanya sisanya $44.10 \%$ dipengaruhi oleh faktor-faktor yang lain.
\end{abstract}

Kata kunci : Lingkungan kerja, Kepemimpinan, Kinerja petani.

\begin{abstract}
The purpose of this study was to examine the influence of work environment and leadership on employee performance at Cahaya Agribiz. Pagelaran, Cianjur Regency. The research method used is descriptive and associative methods. In this study using primary data by observing and distributing questionnaires to respondents. The entire population was used as the object of research so that the sample in this study were 24 farmers. The independent variable in this study was work environment (X1), leadership (X2) while the dependent variable was employee performance $(Y)$. The hypothesis test statistic used is the Spearman Rank. The results of this study are as follows that in general the work environment in Cahaya Agribiz Pagelaran, Cianjur Regency has been considered good by respondents with an average level of achievement of $73.03 \%$, while the leadership at Cahaya Agribiz Pagelaran, Cianjur Regency is felt good, this is shown on average the level of achievement is $79.79 \%$, and in general the performance of employees at Cahaya Agribiz. Pagelaran, Cianjur Regency has an average level of acbievement of $81.15 \%$. The influence
\end{abstract}

PENGARUH LINGKUNGAN KERJA DAN

NURJAYA 
between work environment and leadership on employee performance is indicated by the degree of relationship of 0.641, which is in the range between 0.51-0.75 indicating a relationship that is "strong enough". This means that the influence of the work environment and leadership together can improve employee performance at Cahaya Agribiz Pagelaran, Cianjur Regency and this shows the value of the closeness of the relationship is positive (+).While the magnitude of the influence of work environment and leadership on employee performance is $45.90 \%$ (coefficient of determination), and the rest $44.10 \%$ is influenced by other factors.

Keywords : Work environment, Leadership, Employee performance.

PENGARUH LINGKUNGAN KERJA DAN

NURJAYA 


\section{PENDAHULUAN}

Pada era globalisasi seperti sekarang ini persaingan Perusahaan Perusahaan ataupun Perusahaan sejenis baik kecil, menengah, maupun besar mengakibatkan semakin ketatnya persaingan diantara Perusahaan tersebut. Untuk mengantisipasi situasi yang demikian, pimpinan Perusahaan atau Perusahaan harus selalu berusaha untuk meningkatkan kualitas dan kuantitas sumber daya manusia agar Perusahaan yang dipimpinnya mampu mengantarkan Perusahaan untuk mencapai tujuan yang diharapkan sebelumnya.

Setiap pembicaraan tentang organisasi tentu tidak akan terlepas dari kepemimpinan. Sebuah organisasi dijalankan dan diatur oleh seorang pemimpin. Kepemimpinan merupakan usaha yang dijalankan untuk mempengaruhi anggota kelompok agar mereka dengan suka rela menyumbangkan kemampuannya secara maksimal demi pencapaian tujuan kelompok yang telah ditetapkan.

Teori-teori tentang kepemimpinan telah banyak diteliti orang dengan maksud untuk mengetahui bagaimana sebenarnya kepemimpinan yang baik dan berhasil itu. Disamping itu teori-teori kepemimpinan dimaksud untuk mengetahui unsur-unsur apa saja yang membentuk pribadi seseorang sehingga diketahui sebagai seorang pemimpin yang disegani dan diikuti kepemimpinannya. Seluruh kepribadian tentang kepemimpinan telah dicoba untuk dianalisis seperti: keadaan fisik, kehidupan sosial, imajinasi, kesabaran, kejujuran, intelegensia, dan lain sebagainya.

Pemimpin yang ideal dituntut harus mampu mengenal identitas dirinya secara tepat dan benar. Selain itu pemimpin juga harus bisa memberikan dan menunjukkan keteladanan hidupnya. Lebih jauh lagi pemimpin diharuskan memiliki pengaruh bagi bawahannya atau anggotanya. Hal ini bukan merupakan suatu yang baru di era globalisasi dan komunikasi sekarang ini, tapi sudah menjadi hal lumrah dalam menjalani kehidupan. Salah satu contoh yang tidak bisa ditawar-tawar adalah pengaruh seorang pemimpin bagi semangat kerja Petani nya. Dengan kata lain, pemimpin harus menjadi corong, bertindak sebagai mercusuar yang selalu menerangi, menjadi tongkat penuntun, menjadi pelita bernyala dan bahkan mesti menjadi contoh bagi Petani nya.

Pemimpin Cahaya Agribiz

Kecamatan Pagelaran Kabupaten Cianjur sangat perlu menerapkan hal tersebut karena pemimpin harus mampu menunjukkan sikap, sifat dan tingkah laku yang bagi bawahannya sehingga pemimpin mampu menjadi contoh tempat bertanya bahkan tempat mengeluh baik suka maupun duka bagi Petani . Pada titik inilah seorang mendapat nilai utama skala prioritas, primus interpares, jalan bagi Petani nya dalam dan untuk bekerja. Dengan demikian Petani merasa lebih bersemangat dal $\mathrm{m}$ bekerj, bertanggungjawab terhadap hasil kerjanya dan bersikap loyal terhadap Perusahaan sehingga tujuan Perusahaan dapat tercapai.

Di lain pihak kondisi lingkungan kerja fisikpun sangat berpengaruh terhadap Kinerja Petani. Lingkungan kerja fisik merupakan suatu lingkungan dimana para Petani bekerja dan dapat mempengaruhi mereka dalam menjalankan tugas-tugas yang dibebankan. Faktor-faktor yang termasuk lingkungan kerja fisik adalah pewarnaan, kebersihan, pertukaran udara, penerangan, musik, kebisingan dan ruang gerak.

Lingkungan kerja fisik yang baik akan memberikan kenyamanan pribadi maupun dalam membangkitkan kinerja Petani sehingga dapat mengerjakan tugastugas dengan baik. Faktor lingkungan kerja fisik yang lainnya juga perlu diperhatikan. Disamping itu Petani akan lebih senang dan nyaman dalam bekerja apabila fasilitas yang ada dalam keadaan bersih, tidak bising, pertukaran udara yang cukup baik dan peralatan yang memadai serta relatif modern.

Setiap lembaga selalu ingin meningkatkan kinerja pegawainya 
semaksimal mungkin dalam batas-batas kemampuan Perusahaan. Apabila Perusahaan lalai dalam memperhatikan maka kinerja Petani akan menurun. Indikator yang digunakan untuk melihat kinerja Petani diantaranya adalah tingkat absensi, tingkat perputaran sumber daya manusia (labour turn over), rapat rutin.

Berdasarkan data yang penulis peroleh dari bagian tata usaha maka dapat dikemukakan bahwa dari segi absensi diketahui bahwa jumlah Petani dan tingkat absensi Petani pada Cahaya Agribiz Kecamatan Pagelaran Kabupaten Cianjur secara umum mempunyai tingkat rata-rata sebesar $80.33 \%$. Hal ini menunjukkan bahwa tingkat kehadiran Petani pada Cahaya Agribiz Kecamatan Pagelaran Kabupaten Cianjur cukup baik. Selanjutnya tingkat labour turn over Petani pada Cahaya Agribiz Kecamatan Kecamatan Pagelaran Kabupaten Cianjur mempunyai tingkat rata-rata sebesar 1,94. Hal ini menunjukkan kriteria cukup. Sedangkan dalam temu tani secara berkala sudah dilakukan oleh pihak Cahaya Agribiz agar pimpinan mengetahui bagaimana kinerja Petani dalam bekerja. Disamping itu juga pimpinan harus mengetahui keluhan atau masukan dari Petani selama Petani tersebut bekerja, sehingga akan tercipta hubungan yang baik dan semangat dalam bekerja serta dapat tercapai tujuan Perusahaan .

Berdasarkan uraian latar belakang, maka masalah penelitian ini dapat dirumuskan sebagai berikut:

1. Apakah terdapat pengaruh lingkungan kerja terhadap kinerja Petani pada Cahaya Agribiz Kecamatan Pagelaran Kabupaten Cianjur?

2. Apakah terdapat pengaruh kepemimpinan terhadap kinerja Petani pada Cahaya Agribiz Kecamatan Pagelaran Kabupaten Cianjur?

3. Apakah pengaruh lingkungan kerja dan kepemimpinan terhadap kinerja Petani pada Cahaya Agribiz Kecamatan Pagelaran Kabupaten Cianjur.
Tujuan dari penelitian ini adalah sebagai berikut:

1. Untuk mengetahui pengaruh lingkungan kerja terhadap kinerja Petani pada Cahaya Agribiz Kecamatan Pagelaran Kabupaten Cianjur.

2. Untuk mengetahui pengaruh kepemimpinan terhadap kinerja Petani pada Cahaya Agribiz Kecamatan Pagelaran Kabupaten Cianjur.

3. Untuk mengetahui pengaruh lingkungan kerja dan kepemimpinan terhadap kinerja Petani pada Cahaya Agribiz Kecamatan Pagelaran Kabupaten Cianjur .

Penelitian ini dilakukan mempunyai beberapa manfaat yang diharapkan dapat $m$ e m berikan gambaran mengenai relevansinya antara teoritis dan praktis, diantara kegunaan tersebut adalah:

\section{Manfaat Teoritis}

Hasil penelitian ini secara teori diharapkan dapat memberikan pengembangan pemikiran dalam Ilmu Manajemen Sumber Daya Manusia khususnya mengenai pengaruh lingkungan kerja dan kepemimpinan terhadap kinerja Petani pada Cahaya Agribiz Kecamatan Pagelaran Kabupaten Cianjur .

\section{Manfaat Praktis}

Hasil penelitian mudah-mudahan dapat memberikan masukan kepada pihak-pihak, antara lain:

\section{a. Pihak Penulis}

Sebagai informasi bagi penelitian selanjutnya, dan menambah wawasan bagi penulis khususnya dibidang lingkungan kerja, kepemimpinan dan kinerja Petani yang diaplikasikan dalam Perusahaan pendidikan. 


\section{b. Pihak Pihak lain}

Bagi mudah-mudahan hasil penelitian ini dapat memberikan kontribusi atau masukan sebagai bahan evaluasi guna meningkatkan kegiatan lingkungan kerja dan kepemimpinan, serta kinerja Petani.

\section{c.Perusahaan}

Kontribusi bagi pihak manajemen dapat meningkatkan lingkungan kerja, kepemimpinan serta kinerja Petani pada Cahaya Agribiz Kecamatan Pagelaran Kabupaten Cianjur.

\section{Populasi Dan Teknik Penarikan Sampel}

Populasi dapat didefinisikan sebagai kumpulan dari subjek atau pengukuran dari masalah yang akan diteliti (Bambang S. Soedibjo,2005:101). Populasi dalam penelitian ini seluruh Petani yang ada pada Cahaya Agribiz Kecamatan Pagelaran Kabupaten Cianjur yang berjumlah 24 petani.

Sedangkan Pengertian sampel adalah bagian dari populasi. Sampel berisikan subjek atau anggota yang dipilih dari populasi (Bambang S. Soedibjo, 2005: 102). Karena ukuran populasi terjangkau, maka teknik pengambilan sampel dilakukan dengan teknik sampling penuh (sensus), yaitu semua anggota populasi dijadikan sebagai objek penelitian (responden) yaitu 24 orangPetani Desain Penelitian

Metode penelitian yang digunakan dalam penelitian ini adalah metode deskriptif dan asosiatif. Menurut Bambang. S. Soedibjo (2005:7) metode deskriptif adalah suatu penelitian untuk mengetahui nilai variabel mandiri, sedangkan metode asosiatif digunakan untuk melihat hubungan antara dua atau lebih variabel. Dalam penelitian ini metode deskriptif digunakan untuk melihat gambaran mengenai masing masing variabel mandiri seperti yang ditunjukkan dalam judul penelitian ini, sedangkan metode asosiatif atau metode korelasional untuk melihat hubungan kedua variabel tersebut. Penelitian ini merupakan kajian cross- sectional yaitu penelitia dilakukan hanya satu periode waktu tertentu.

\section{Metode Pengumpulan Data}

Penelitian dilaksanakan di Cahaya Agribiz Kecamatan Pagelaran Kabupaten Cianjur pada bulan Juli sampai Desember 2019.

Teknik pengumpulan data yang digunakan adalah dengan menggunakan angket. Teknik ini dilakukan dengan cara mengedarkan daftar pertanyaan yang harus diisi oleh responden yang akan dijadikan sampel dari populasi. Teknik ini dilakukan untuk mendapatkan data primer dan melengkapi data yang telah didapat dalam hal ini digunakan angket, yaitu memberikan daftar pertanyaan untuk diisi oleh responden yang menjadi sampel dalam penelitian. Seperti yang ditemukan oleh Kartini kartono (1997:200) yaitu " Angket adalah kuesioner suatu penyelidikan mengenai suatu masalah umum dilakukan dengan cara mengedarkan suatu daftar tertulis kepada sejumlah subjek untuk mendapat jawaban atau tanggapan tertulis.

Bentuk pertanyaan yang digunakan adalah bentuk pertanyaan berstruktur atau tertutup yang telah disusun sebelumnya agar maksud dari pertanyaan dapat diketahui dengan jelas. Pertanyaan merupakan kombinasi pilihan ganda dengan skala sikap yang berpedoman pada skala Likert. Skala ini berisi seperangkat pertanyaan yang merupakan pendapat responden mengenai objek sikap. Sikapsikap dari pertanyaan tersebut memperlihatkan pendapat positif. Setiap jenis pendapat dinilai sesuai arah pertanyaan yaitu pertanyaan positif dan skala yang digunakan adalah 5-4-3-21.Untuk lebih jelasnya skala likert yang akan digunakan yaitu: 
Tabel 1. Pembobotan Skala Likert.

\begin{tabular}{|c|c|}
\hline Pilihan Jawaban & Skor Pernyataan Positif (+) \\
\hline Sangat setuju (a) & 5 \\
\hline Setuju (b) & 4 \\
\hline Ragu-ragu (c) & 3 \\
\hline Tidak setuju (d) & 2 \\
\hline Sangat tidak setuju (e) & 1 \\
\hline
\end{tabular}

Sumber : Soegiono (2004:75).

\section{Operasionalisasi Variabel}

Agar konsep variabel yang diajukan dalam penelitian dapat diukur, maka variabel tersebut didefinisikan terlebih dahulu agar terdapat kesamaan persepsi dalam mengkaji konsep yang sedang diteliti. Menurut Bambang. S. Soedibjo (2005 : 47) menyatakan bahwa definisi operasional variabel merupakan definisi kongkrit atau karakteristik konsep atau konstruk yang akan diukur. konsep yang diajukan dalam penelitian ini terdiri dari tiga variabel, yaitu variabel bebas (independent) adalah lingkungan kerja (X1) dan Kepemimpinan (X2) dan variabel terikat (dependent) adalah Kinerja Petani (Y).

\section{Analisis Data}

Analisis data dalam hal ini dilakukan secara kuantitatif dengan menggunakan analisis korelasi dan analisis koefisien determinasi. Dengan Uji Validitas Instrumen Penelitian dan Uji Reliabilitas Instrumen Penelitian.

Analisis hubungan menggunakan analisis korelasi spearman. Analisis ini dimaksudkan untuk mengetahui tingkat derajat antara variabel bebas " $\mathrm{X}$ " dengan variabel tidak bebas "Y", ukuran yang digunakan untuk menyatakan tingkat derajat disebut koefisien korelasi " $\mathrm{r}$ "

\section{Rancangan Pengujian Hipotesis}

Penelitian ini dilakukan dengan menggunakan metode analisis regresi berganda (multiple regression) untuk mengetahui pola perubahan nilai variabel yang disebabkan oleh variabel lain dan untuk menemukan tingkat keeratan hubungan variabel yang berbeda dalam suatu populasi.
Pengujian ini dilakukan menggunakan distribusi $F$ dengan membandingkan antara nilai $\mathrm{F}$ - kritis dengan nilai $\mathrm{F}$ - test yang terdapat pada Tabel Analisis of Variance (ANOVA) dari hasil perhitungan dengan microstat. Jika nilai $\mathrm{F}$ hitung $>\mathrm{F}$ kritis, maka $\mathrm{H} 0$ yang menyatakan bahwa variasi perubahan nilai variabel terikat (kinerja Petani) ditolak dan sebaliknya.

H 1 : Terdapat pengaruh lingkungan kerja dengan kinerja pada Cahaya Agribiz Kecamatan Pagelaran Kabupaten Cianjur .

H 2 : Terdapat pengaruh kepemimpinan dengan kinerja Petani pada Cahaya Agribiz Kecamatan Pagelaran Kabupaten Cianjur

H 3: Terdapat pengaruh lingkungan kerja dan kepemimpinan terhadap kinerja Petani pada Cahaya Agribiz Kecamatan Pagelaran Kabupaten Cianjur .

\section{HASIL DAN PEMBAHASAN}

Untuk mengetahui penilaian dari masing-masing variabel dan juga untuk memudahkan penilaian kembali dicari kelas interval. Menurut Sujana (2000:131) menyatakan banyaknya kelas sering atau biasanya diambil paling sedikit 5 kelas .Katagori penilaian masing-masing kelas, sebagai berikut:

$81-100$ : sangat baik

$61-80$ : Baik

$41-60$ : Cukup Baik

$21-40$ : Kurang baik

$0-20$ : Sangat kurang baik 


\section{Penilaian Lingkungan Kerja}

Variabel (X1) yaitu lingkungan kerja ruang pertemuan temu tani diukur dari 6 dimensi: 1) Penerangan 2) Suhu udara 3) Ruang gerak 4) Keamanan 5) kebersihan dan 6) Suara Bising.

\section{Deskripsi Tanggapan Responden terhadap Dimensi Penerangan \\ Berdasarkan hasil jawaban} responden maka diperoleh hasilnya yaitu tertera dalam tabel dibawah ini:

Tabel 2. Tanggapan Responden Terhadap Dimensi Penerangan

\begin{tabular}{|c|c|c|c|c|c|c|c|c|c|c|}
\hline No & Penyataan & SS & S & $\mathbf{R R}$ & TS & STS & f & S.Aktual & S.Ideal & Pencapaian \\
\hline 1 & $\begin{array}{l}\text { Warna dalam } \\
\text { ruangan }\end{array}$ & 2 & 10 & 9 & 2 & 1 & 24 & 82 & 120 & 68.33 \\
\hline 2 & $\begin{array}{l}\text { Penerangan } \\
\text { Lampu }\end{array}$ & 4 & 17 & 2 & 1 & & 24 & 96 & 120 & 80.00 \\
\hline \multicolumn{10}{|c|}{ Rata-Rata } & 74.17 \\
\hline
\end{tabular}

Sumber: Data yang sudah diolah 2020.

Dari tabel di atas dapat dilihat bahwa tingkat pencapaian untuk indikator "Warna dalam ruangan" sebesar $68.33 \%$, ini masuk katagori baik, indikator"Penerangan lampu" sebesar $80.00 \%$, ini masuk katagori sangat baik. Sedangkan rata-rata tingkat pencapaian untuk dimensi Penerangan sebesar $74.17 \%$, ini masuk katagori baik.

\section{Deskripsi Tanggapan Responden} terhadap Dimensi Suhu Udara

Berdasarkan hasil jawaban responden maka diperoleh hasilnya yaitu tertera dalam tabel dibawah ini:

Tabel 3. Tanggapan Responden Terhadap Dimensi Suhu Udara.

\begin{tabular}{clccccccccc}
\hline No & Penyataan & SS & S & RR & TS & STS & f & S.Aktual & S.Ideal & Pencapaian \\
\hline 1 & $\begin{array}{l}\text { Ventilasi dan } \\
\text { Alat Bantu }\end{array}$ & 4 & 10 & 4 & 6 & 24 & 84 & 120 & 70.00 \\
\hline \multicolumn{8}{c}{ Rata-Rata } \\
\hline
\end{tabular}

Sumber: Data yang sudah diolah 2020.

Dari tabel di atas dapat dilihat bahwa tingkat pencapaian untuk indikator"Ventilasi dan alat bantu" sebesar $70.00 \%$, ini masuk katagori baik. Sedangkan tingkat pencapaian untuk dimensi Suhu Udara sebesar $70.00 \%$, ini masuk katagori baik.

\section{Deskripsi Tanggapan Responden} terhadap Dimensi Ruang Gerak

Berdasarkan hasil jawaban responden maka diperoleh hasilnya yaitu tertera dalam tabel dibawah ini:

Tabel 4. Tanggapan Responden Terhadap Dimensi Ruang Gerak

\begin{tabular}{ccccccccccc}
\hline No & Penyataan & SS & S & RR & TS & STS & f & S.Aktual & S.Ideal & Pencapaian \\
\hline 1 & Ruang Gerak & 1 & 16 & 7 & & 24 & 90 & 120 & 75.00 \\
\hline \multicolumn{10}{c}{ Rata-Rata } \\
\hline
\end{tabular}

Sumber: Data yang sudah diolah 2020.

Dari tabel di atas dapat dilihat bahwa tingkat pencapaian untuk indikator yang menyatakan "ruang gerak" sebesar $75.00 \%$, ini masuk katagori baik. Sedangkan tingkat pencapaian untuk dimensi ruang gerak sebesar $75.00 \%$, ini masuk katagori baik.

\section{Deskripsi Tanggapan Responden terhadap Dimensi Keamanan}

Berdasarkan hasil jawaban responden maka diperoleh hasilnya yaitu tertera dalam tabel dibawah ini: 
Tabel 5. Tanggapan Responden Terhadap Dimensi Keamanan

\begin{tabular}{|c|c|c|c|c|c|c|c|c|c|c|}
\hline No & Penyataan & SS & $\mathbf{S}$ & $\mathbf{R R}$ & TS & STS & f & S.Aktual & S.Ideal & Pencapaian \\
\hline 1 & Antisipasi & 5 & 17 & 1 & 1 & & 24 & 98 & 120 & 81.67 \\
\hline 2 & $\begin{array}{l}\text { Renovasi } \\
\text { Bangunan }\end{array}$ & 2 & 5 & 10 & 7 & & 24 & 74 & 120 & 61.67 \\
\hline 3 & $\begin{array}{l}\text { Tingkat } \\
\text { Keamanan }\end{array}$ & 2 & 13 & 7 & 2 & & 24 & 87 & 120 & 72.50 \\
\hline \multicolumn{10}{|c|}{ Rata-Rata } & 71.94 \\
\hline
\end{tabular}

Sumber: Data yang sudah diolah 2020.

Dari tabel di atas dapat dilihat bahwa tingkat pencapaian untuk indikator"antisipasi" sebesar 81.67\%, ini masuk katagori sangat baik. Selanjutnaya indicator "renovasi bangunan" sebesar $61.67 \%$, ini masuk katagori baik. Kemudian indicator "tingkat keamanan" sebesar $72.50 \%$, ini masuk katagori baik. Sedangkan rata-rata tingkat pencapaian untuk dimensi keamanan sebesar 71.94\%, ini masuk katagori baik.

\section{Deskripsi Tanggapan Responden terhadap Dimensi Kebersihan}

Berdasarkan hasil jawaban responden maka diperoleh hasilnya yaitu tertera dalam tabel dibawah ini:

Tabel 6. Tanggapan Responden Terhadap Dimensi Kebersihan

\begin{tabular}{ccccccccccc}
\hline No & Penyataan & SS & S & RR & TS & STS & f & S.Aktual & S.Ideal & Pencapaian \\
\hline $1 \begin{array}{l}\text { Kondisi tertata } \\
\text { bersih/rapi }\end{array}$ & 6 & 8 & 10 & 24 & 92 & 120 & 76.67 \\
\hline \multicolumn{8}{c}{ Rata-Rata } \\
\hline
\end{tabular}

Sumber: Data yang sudah diolah 2020 .

Dari tabel di atas dapat dilihat bahwa tingkat pencapaian untuk indikator yang menyatakan "kondisi tertata rapi / bersih" sebesar 76.67\%, ini masuk katagori baik. Sedangkan tingkat pencapaian untuk dimensi kebersihan sebesar 76.67\%, ini masuk katagori baik.
6. Deskripsi Tanggapan Responden Terhadap Dimensi Musik

Berdasarkan hasil jawaban responden maka diperoleh hasilnya yaitu tertera dalam tabel di bawah ini:

Tabel 7. Tanggapan Responden terhadap Dimensi Suara Bising Ruang Temu Tani.

\begin{tabular}{clccccccccc}
\hline No & \multicolumn{1}{c}{ Penyataan } & SS & S & RR & TS & STS & f & S.Aktual & S.Ideal & Pencapaian \\
\hline 1 & Tingkat & 3 & 15 & 6 & & 24 & 9 & 120 & 77.50 \\
\multirow{2}{*}{2} & $\begin{array}{l}\text { Peralatan yang } \\
\text { Canggih }\end{array}$ & 8 & 9 & 6 & 24 & 7 & 120 & 63.33 \\
\hline \multicolumn{7}{c}{ Rata-Rata } & & 6 & & 70.42 \\
\hline
\end{tabular}

Sumber: Data yang sudah diolah 2020.

Dari tabel di atas dapat dilihat bahwa tingkat pencapaian untuk indikator"tingkat kebisingan" sebesar $77.50 \%$, ini masuk katagori baik. Selanjutnya untuk indikator"peralatan yang canggih" sebesar $63.33 \%$, ini masuk katagori kurang baik. Sedangkan rata-rata tingkat pencapaian untuk dimensi musik sebesar $70.42 \%$, ini masuk katagori baik.

Dari hasil penilaian 5 dimensi lingkungan kerja di atas, maka dapat disimpulkan bahwa secara keseluruhan nilai rata-rata persentase persetujuan responden terhadap variabel lingkungan 
kerja sebesar $73.03 \%$ hasil ini mencerminkan bahwa lingkungan kerja sudah baik.

\section{Deskripsi Kepemimpinan}

Kepemimpinan diukur dari 3 dimensi 1) Hubungan Pimpinan dan
Petani , 2) Struktur Tugas, dan 3) Kekuatan Posisi.

\section{Dimensi Hubungan Pimpinan dan Petani \\ Berdasarkan hasil jawaban} responden maka diperoleh hasilnya yaitu tertera dalam tabel dibawah ini :

Tabel 8. Tanggapan Responden terhadap Dimensi Hubungan Pimpinan dan Petani .

\begin{tabular}{clccccccccc}
\hline No & Penyataan & SS & S & RR & TS & STS & f & S.Aktual & S.Ideal & Pencapaian \\
\hline 1 & Tingkat & 4 & 16 & 4 & 24 & 96 & 120 & 80.00 \\
2 & Keyakinan & 7 & 11 & 6 & 24 & 97 & 120 & 80.83 \\
3 & Rasa Hormat & 10 & 10 & 4 & 24 & 102 & 120 & 85.00 \\
\hline \multicolumn{7}{r}{ Rata-Rata } \\
\hline
\end{tabular}

Sumber: Data yang sudah diolah 2020.

Dari tabel di atas dapat dilihat bahwa tingkat pencapaian untuk indikator"tingkat kepercayaan" sebesar $80.00 \%$ ini masuk katagori sangat baik. Selanjutnya indikator yang menyatakan "Keyakinan" sebesar $80.83 \%$, ini masuk katagori sangat baik. Kemudian untuk indikator"rasa hormat" sebesar $85.00 \%$, ini masuk katagori sangatuntuk dimensi Hubungan Pimpinan dan Petani sebesar $81.94 \%$, ini masuk katagori sangat baik.

\section{Dimensi Struktur Tugas}

Berdasarkan hasil jawaban responden maka diperoleh hasilnya yaitu tertera dalam tabel dibawah ini:

Tabel 9. Tanggapan Responden terhadap Dimensi Struktur Tugas.

\begin{tabular}{|c|c|c|c|c|c|c|c|c|c|c|}
\hline No & Penyataan & SS & $\mathbf{S}$ & $\mathbf{R R}$ & TS & STS & f & S.Aktual & S.Ideal & Pencapaian \\
\hline 1 & $\begin{array}{l}\text { Prosedur } \\
\text { Tugas }\end{array}$ & 7 & 9 & 8 & & & 24 & 95 & 120 & 79.17 \\
\hline 21 & $\begin{array}{l}\text { Menertibkan } \\
\text { Petani }\end{array}$ & 5 & 11 & 8 & & & 24 & 93 & 120 & 77.50 \\
\hline 3 & $\begin{array}{l}\text { Mempekerjakan } \\
\text { Petani }\end{array}$ & 10 & 13 & 1 & & & 24 & 105 & 120 & 87.50 \\
\hline
\end{tabular}

Sumber: Data yang sudah diolah 2020.

Dari tabel di atas dapat dilihat bahwa tingkat pencapaian untuk indikator"prosedur tugas kerja" sebesar $79.17 \%$, ini masuk katagori baik. Selanjutnya untuk indicator "Menertibkan Petani" sebesar $77.50 \%$, ini masuk katagori baik. Selanjutnya untuk indikator" Mempekerjakan Petani " sebesar $87.50 \%$, ini masuk katagori sangat baik. Sedangkan rata-rata tingkat pencapaian untuk dimensi struktur tugas sebesar $81.39 \%$, ini masuk katagori sangat baik.

\section{Dimensi Kekuatan Posisi}

Berdasarkan hasil jawaban responden maka diperoleh hasilnya yaitu tertera dalam tabel dibawah ini 
Tabel 10. Tanggapan Responden terhadap Dimensi Kekuatan Posisi.

\begin{tabular}{|c|c|c|c|c|c|c|c|c|c|c|}
\hline No & Penyataan & SS & $\mathbf{S}$ & $\mathbf{R R}$ & TS & STS & f & S.Aktual & S.Ideal & Pencapaian \\
\hline 1 & $\begin{array}{l}\text { Tugas-tugas } \\
\text { Kerja }\end{array}$ & 1 & 7 & 13 & 3 & & 24 & 78 & 120 & 65.00 \\
\hline 2 & $\begin{array}{l}\text { Menaikan } \\
\text { Upah }\end{array}$ & 2 & 9 & 11 & 2 & & 24 & 83 & 120 & 69.17 \\
\hline 3 & $\begin{array}{l}\text { Kekuasaan } \\
\text { Mencatat } \\
\text { Produksi }\end{array}$ & 12 & 11 & 1 & & & 24 & 107 & 120 & 89.17 \\
\hline 4 & $\begin{array}{l}\text { Menaikan } \\
\text { Pendapatan }\end{array}$ & 8 & 9 & 7 & & & 24 & 97 & 120 & 80.83 \\
\hline \multicolumn{10}{|c|}{ Rata-Rata } & 76.04 \\
\hline
\end{tabular}

Sumber: Data yang sudah diolah 2020.

Dari table di atas dapat dilihat bahwa tingkat pencapaian untuk indikatorb"Tugas- tugas kerja" sebesar $65.00 \%$,ini masuk katagori baik. Selanjutnya untuk indikator"Menaikan pangkat" sebesar 69.17\%, ini masuk katagori baik. Selanjutnya untuk indikator"Kekuasaan Mencatat" sebesar 89.17\%,ini masuk katagori sangat baik. Kemudian untuk indikator"Menaikan Gaji" sebesar 80.83\%, ini masuk katagori sangat baik. Sedangkan rata-rata tingkat pencapaian untuk dimensi Kekuatan Posisi sebesar $76.04 \%$, ini masuk katagori baik. Berdasarkan hasil penilaian dari 3 dimensi kepemimpinan di atas,dapat disimpulkan bahwa rata-rata tingkat pencapaian persetujuan responden untuk variabel Kepemimpinan mencapai $79.79 \%$, hasil ini mencerminkan bahwa kondisi kepemimpinan dalam kondisi baik.

\section{Deskripsi Kinerja Petani}

Kinerja Petani diukur dari 4 dimensi yaitu: 1) Etika kerja, 2) Kualitas kerja, 3) Kreatif dan 4) Pengetahuan kerja.

\section{Dimensi Etika Kerja}

Berdasarkan hasil jawaban responden maka diperoleh hasilnya yaitu tertera dalam tabel dibawah ini:

Tabel 11. Tanggapan Responden terhadap Dimensi Etika Kerja

\begin{tabular}{ccccccccccc}
\hline No & Penyataan & SS & S & RR & TS & STS & f & S.Aktual & S.Ideal & Pencapaian \\
\hline 1 & Ketepatan & 11 & 12 & 1 & 24 & 106 & 120 & 88.33 \\
2 & Keterampilan & 7 & 15 & 2 & & 24 & 101 & 120 & 84.17 \\
\hline \multicolumn{7}{c}{ Rata-Rata } & & & & 86.25 \\
\hline
\end{tabular}

Sumber: Data yang sudah diolah 2020

Dari tabel di atas dapat dilihat bahwa tingkat pencapaian untuk indikator"Pekerjaan dapat diselesaikan dengan prosedur" sebesar 88.33\% ini masuk kategori sangat baik. Selanjutnya untuk indikator"Pekerjaan dapat diselesaikan sesuai dengan waktu" sebesar $84.17 \%$ ini masuk kategori sangat baik. Sedangkan rata-rata tingkat pencapaian untuk dimensi Etika Kerja sebesar $86.25 \%$, ini masuk kategori sangat baik.

\section{Dimensi Kualitas Kerja}

Berdasarkan hasil jawaban responden maka diperoleh hasilnya yaitu tertera dalam tabel dibawah ini: 
Tabel 12. Tanggapan responden terhadap Dimensi Kualitas Kerja.

\begin{tabular}{|c|c|c|c|c|c|c|c|c|c|c|}
\hline No & Penyataan & SS & S & $\mathbf{R R}$ & TS & STS & f & S.Aktual & S.Ideal & Pencapaian \\
\hline 1 & Hasil Panen & 5 & 14 & 5 & & & 24 & 96 & 120 & 80.00 \\
\hline 2 & $\begin{array}{l}\text { Mengikuti } \\
\text { Instruksi } \\
\text { (SOP)Budidaya }\end{array}$ & 12 & 7 & 5 & & & 24 & 103 & 120 & 85.83 \\
\hline \multicolumn{10}{|c|}{ Rata-Rata } & 82.92 \\
\hline
\end{tabular}

Sumber: Data yang sudah diolah 2020.

Dari tabel di atas dapat dilihat bahwa tingkat pencapaian untuk indikator"Kuantitas pekerjaan sesuai target" sebesar $80.00 \%$ ini masuk kategori baik.Selanjutnya untuk indikator" mengikuti instruksi" sebesar $85.83 \%$ ini masuk kategori sangat baik. Sedangkan rata-rata tingkat pencapaian untuk dimensi Kualitas Kerja sebesar 82.92\%, ini masuk kategori sangat baik.

\section{Dimensi Kreatif}

Berdasarkan hasil jawaban responden maka diperoleh hasilnya yaitu tertera dalam tabel dibawah ini:

Tabel 13. Tanggapan responden terhadap Dimensi Kreatif.

\begin{tabular}{ccccccccccc}
\hline No & Penyataan & SS & S & RR & TS & STS & f & S.Aktual & S.Ideal & Pencapaian \\
\hline 1 & Inisiatif & 8 & 14 & 2 & & 24 & 102 & 120 & 85.00 \\
2 & Inovatif & 5 & 17 & 1 & 1 & 24 & 98 & 120 & 81.67 \\
\hline \multicolumn{7}{c}{ Rata-Rata } & & & & 83.33 \\
\hline
\end{tabular}

Sumber: Data yang sudah diolah 2020.

Dari tabel di atas dapat dilihat bahwa tingkat pencapaian untuk indikator"'inovatif" sebesar 85.00\% ini masuk kategori sangat baik. Selanjutnya untuk indikator yang menyatakan "inovatif" sebesar $81.67 \%$ ini masuk kategori sangat baik. Sedangkan tingkat pencapaian untuk dimensi Kreatif sebesar $83.33 \%$, ini masuk kategori sangat baik
Hasil ini mencerminkan bahwa dimensi Kreatif sudah menunjukkan kondisi yang baik.

\section{Dimensi Pengetahuan Kerja}

Berdasarkan hasil jawaban responden maka diperoleh hasilnya yaitu tertera dalam tabel dibawah ini:

Tabel 14. Tanggapan responden terhadap Dimensi Pengetahuan Kerja.

\begin{tabular}{|c|c|c|c|c|c|c|c|c|c|c|}
\hline No & Penyataan & SS & S & $\mathbf{R R}$ & TS & STS & f & S.Aktual & S.Ideal & Pencapaian \\
\hline 1 & $\begin{array}{l}\text { Sikap Terhadap } \\
\text { Bawahan }\end{array}$ & 1 & 10 & 7 & 6 & & 24 & 78 & 120 & 65.00 \\
\hline 2 & $\begin{array}{l}\text { Sikap Terhadap } \\
\text { Pekerjaan }\end{array}$ & 3 & 17 & 4 & & & 24 & 95 & 120 & 79.17 \\
\hline & & & & & Rata & & & & & 72.08 \\
\hline
\end{tabular}

Sumber: Data yang sudah diolah 2020.

Dari tabel di atas dapat dilihat bahwa tingkat pencapaian untuk indikator "Sikap terhadap bawahan" sebesar $65.00 \%$ ini masuk kategori cukup baik. Selanjutnya untuk indikator"Sikap terhadap pekerjaan" sebesar 79.17\% ini masuk kategori baik. Sedangkan ratarata tingkat pencapaian Pengetahuan kerja sebesar 72.08\%, ini masuk kategori baik Hasil ini mencerminkan bahwa dimensi Pengetahuan Kerja sudah menunjukkan kondisi yang baik.

Berdasarkan hasil penilaian dari 3 dimensi maka dapat disimpulkan rata-rata tingkat pencapaian persetujuan responde untuk variabel Kinerja Petani 
(Variabel Y) mencapai 81.15\%, hasil ini mencerminkan bahwa kondisi Kinerja Petani dalam kondisi yang sangat baik.

\section{Pengaruh Lingkungan Kerja dengan Kinerja Petani}

Hipotesis pertama menyangkut masalah pengaruh dari Lingkungan
Kerja (X1) terhadap Kinerja (Y). Perhitungan dengan SPSS 11.5 atas pengaruh dari Lingkungan Kerja (X1) dengan Kinerja $(\mathrm{Y})$ menghasilkan persamaan regresi $=0,561+0,501 \mathrm{X} 1$, dengan analisis variansi dan hasil pengujian sebagai berikut:

Tabel 15. Pengaruh Kepemimpinan (X2) dengan Kinerja (Y).

\begin{tabular}{clccccc}
\hline \multirow{2}{*}{ Model } & \multicolumn{7}{c}{$\begin{array}{c}\text { Unstandardized } \\
\text { Coefficients }\end{array}$} & $\begin{array}{c}\text { Standardized } \\
\text { Coefficients }\end{array}$ & \multirow{2}{*}{ t } & \multirow{2}{*}{ Sig. } \\
\cline { 2 - 5 } & \multicolumn{7}{c}{ B } & Std. Error & Beta & & \\
\hline \multirow{2}{*}{1} & (Constant) & 4.664 & 1.055 & & 4.419 & .000 \\
& $\mathrm{X} 2$ & .520 & .265 & .412 & 6.573 & .000 \\
\hline
\end{tabular}

a. Dependent Variable : Y

\begin{tabular}{ccrrr}
\hline Model & $\mathbf{R}$ & R Square & Adjusted R Square & Std. Error of the Estimate \\
\hline 1 & $.412(\mathrm{a})$ & .370 & .301 & .29897 \\
\hline a. Predictors: (Constant), X2 & & & \\
\hline
\end{tabular}

Berdasarkan tabel di atas terlihat bahwa pengaruh Lingkungan Kerja $\left(\mathrm{X}_{1}\right)$ dengan Kinerja (Y) adalah sebesar 0,539 (Standardized Coefficients), dengan Sig. $t$ sebesar $0,000<0,05$ atau nilai thitung sebesar 4,068 $>2$, maka dapat dikatakan bahwa Lingkungan Kerja $\left(\mathrm{X}_{1}\right)$ terbukti berpengaruh secara signifikan terhadap Kinerja $(\mathrm{Y})$, serta pengaruhnya positif dengan kontribusi sebesar $45.6 \%$. Sedangkan pengaruh faktor lain sebesar $54.4 \%$ yang harus diteliti lebih lanjut.
Tabel di atas menyimpulkan bahwa hipotesis H1 didukung data (diterima), hal ini berarti bahwa lingkungan kerja terbukti berpengaruh positif terhadap Kinerja. Hasil ini sesuai dengan prediksi awal (hipotesis), bahwa semakin baik lingkungan kerja, maka kinerja akan semakin tinggi.

Sedangkan untuk mengetahui persamaan regresi antara Lingkungan Kerja $\left(X_{1}\right)$ dengan Kinerja $(Y)$, maka dapat dilihat pada tabel di bawah ini

Tabel 16. Anova uji signifikansi dan linearitas Regritas $\left(\mathrm{X}_{1)}\right.$ dan $(\mathrm{Y})$.

\begin{tabular}{llrrrrc}
\multicolumn{7}{c}{ ANOVA(b) } \\
\hline Model & Sum of Squares & df & Mean Square & F & Sig. \\
\hline 1 & Regression & .690 & 1 & .065 & $\mathbf{8 . 5 6 7}$ & $.000(\mathrm{a})$ \\
& Residual & 1.996 & 22 & .091 & & \\
\cline { 2 - 7 } & Total & 1.996 & 23 & & & \\
\hline
\end{tabular}

a. Predictors: (Constant), X1

b. Dependent Variable: Y

Berdasarkan diatas terlihat bahwa Sig.F $(0,000)<0,05$ atau nilai Fhitung (8.567) $>2$, maka persamaan regresi dapat dikatakan sangat signifikan. Apabila disimpulkan berdasarkan persamaan regresi $=0,561+0,501 \mathrm{X} 1$, maka dapat diartikan bahwa setiap kenaikan 1 unit skor Lingkungan Kerja akan menyebabkan kenaikan skor Kinerja Petani sebesar 0,501 pada konstanta 0,561 . 
Pengaruh Kepemimpinan dengan Kinerja Petani

Hipotesis kedua menyangkut masalah pengaruh dari Kepemimpinan (X2) terhadap Kinerja Petani (Y). Perhitungan dengan SPSS 11.5 atas pengaruh dari Kepemimpinan (X2) dengan Kinerja Petani ( Y ) menghasilkan persamaan regresi $=0,561+$ $0,520 \mathrm{X} 1$, dengan analisis variansi dan hasil pengujian sebagai berikut :

Tabel 17. Pengaruh Kepemimpinan (X2) dengan Kinerja (Y).

\begin{tabular}{|c|c|c|c|c|c|c|}
\hline \multirow{2}{*}{ Model } & & \multicolumn{2}{|c|}{$\begin{array}{l}\text { Unstandardized } \\
\text { Coefficients }\end{array}$} & \multirow{2}{*}{$\begin{array}{c}\begin{array}{c}\text { Standardized } \\
\text { Coefficients }\end{array} \\
\text { Beta }\end{array}$} & \multirow[t]{2}{*}{$\mathbf{t}$} & \multirow{2}{*}{ Sig. } \\
\hline & & B & Std. Error & & & \\
\hline \multirow[t]{2}{*}{1} & (Constant) & 4.664 & 1.055 & & 4.419 & .000 \\
\hline & $\mathrm{X} 2$ & .520 & .265 & .412 & 6.573 & .000 \\
\hline
\end{tabular}

a. Dependent Variable : $\mathrm{Y}$

\begin{tabular}{crrrr}
\hline Model & $\mathbf{R}$ & R Square & Adjusted R Square & Std. Error of the Estimate \\
\hline 1 & $.412(\mathrm{a})$ & .370 & .301 & .29897 \\
\hline a. Predictors: (Constant), X2 & & &
\end{tabular}

Berdasarkan tabel diatas terlihat bahwa pengaruh Kepemimpinan (X2) dengan Kinerja $(\mathrm{Y})$ adalah sebesar 0,412 (Standardized Coefficients), dengan Sig. $t$ sebesar $0,000<0,05$ atau nilat thitung sebesar 6,573 > 2, maka dapat dikatakan bahwa Kepemimpinan (X2) terbukti berpengaruh secara signifikan terhadap Kinerja Petani (Y), serta pengaruhnya positif dengan kontribusi sebesar $37.0 \%$. Sedangkan pengaruh faktor lain sebesar $63.0 \%$ yang harus diteliti lebih lanjut.

Tabel di atas menyimpulkan bahwa hipotesis H1 didukung data (diterima), hal ini berarti bahwa kepemimpinan terbukti berpengaruh positif terhadap kinerja Petani . Hasil ini sesuai dengan prediksi awal (hipotesis), bahwa semakin baik kepemimpinan, maka kinerja Petani akan semakin tinggi. Sedangkan untuk mengetahui persamaan regresi antara Kepemimpinan (X2) dengan Kinerja Petani (Y), maka dapat dilihat pada tabel di bawah.
Berdasarkan diatas terlihat bahwa Sig.F $(0,000)<0,05$ atau nilai Fhitung (8.328) $>2$, maka persamaan regresi dapat dikatakan sangat signifikan. Apabila disimpulkan berdasarkan persamaan regresi $=0,561+0,520 \mathrm{X}_{2}$, maka dapat diartikan bahwa setiap kenaikan 1 unit skor Kepemimpinan akan menyebabkan kenaikan skor Kinerja Petani sebesar 0,520 pada konstanta 0,561 .

\section{Pengaruh Lingkungan Kerja dan Kepemimpinan terhadap Kinerja Petani}

Hipotesis ketiga menyangkut masalah pengaruh dari Lingkungan Kerja $\left(\mathrm{X}_{1}\right)$ dan Kepemimpinan $\left(\mathrm{X}_{2}\right)$ terhadap Kinerja Petani (Y). Perhitungan dengan SPSS 11.5 atas pengaruh dari Lingkungan Kerja $\left(\mathrm{X}_{1}\right)$ dan Kepemimpinan $\left(\mathrm{X}_{2}\right)$ dengan Kinerja Petani (Y) menghasilkan persamaan regresi $=0,561+0,305 \mathrm{X}_{1}+0,480 \mathrm{X}_{2}$, dengan analisis variansi dan hasil pengujian sebagai berikut : 
Tabel 17. Pengaruh lingkungan kerja (X1) dan kepemimpinan (X2) dengan kinerja pegawai (Y).

\begin{tabular}{|c|c|c|c|c|c|c|}
\hline \multirow{2}{*}{ Model } & & \multicolumn{2}{|c|}{$\begin{array}{l}\text { Unstandardized } \\
\text { Coefficients }\end{array}$} & \multirow{2}{*}{$\begin{array}{l}\text { Standardized } \\
\text { Coefficients }\end{array}$} & \multirow[t]{2}{*}{$\mathrm{t}$} & \multirow{2}{*}{ Sig. } \\
\hline & & B & Std. Error & & & \\
\hline 1 & (Constant) & .561 & 1.088 & & 4.463 & .000 \\
\hline & $\mathrm{X} 1$ & 305 & .368 & .315 & 3.829 & .000 \\
\hline & $\mathrm{X} 2$ & 480 & .477 & .383 & 4.005 & .000 \\
\hline
\end{tabular}

a. Dependent Variable : Y

\begin{tabular}{crrrrr}
\hline Model & $\mathbf{R}$ & R Square & Adjusted R Square & Std. Error of the Estimate \\
\hline 1 & $.614(\mathrm{a})$ & .459 & .449 & .30112 \\
\hline a. Predictors: (Constant), X2, X1 & & & \\
\hline
\end{tabular}

Berdasarkan tabel di atas, jelas bahwa pengaruh lingkungan kerja terhadap Kinerja Petani sebesar 0,315 dengan nilai thitung $(3,829)>2$ atau sig level $0.000<0.05$ dapat dikatakan pengaruhnya signifikan, demikian juga pengaruh kepemimpinan terhadap kinerja Petani sebesar 0,383, dengan nilai thitung $(4,005)>2$ atau sig. level $0,000<$ 0,05 dapat dikatakan juga hubungannya signifikan, demikian juga pengaruh lingkungan kerja dan kepemimpinan secara simultan terhadap kinerja Petani sebesar 0,614, atau sebesar $45.90 \%$ dapat dikatakan juga hubungannya signifikan serta pengaruhnya positif dengan kontribusi sebesar $45.90 \%$. Sedangkan pengaruh faktor lain sebesar $44.10 \%$ yang harus diteliti lebih lanjut. Tabel di atas menyimpulkan bahwa hipotesis $\mathrm{H} 3$ didukung data (diterima), hal ini berarti bahwa lingkungan kerja dan kepemimpinan terbukti secara bersamasama berpengaruh positif terhadap kinerja, baik secara parsial maupun secara bersama- sama. Hasil ini sesuai dengan prediksi awal (hipotesis), bahwa semakin baik lingkungan kerja dan kepemimpinan, maka kinerja Petani akan semakin tinggi.

Sedangkan untuk mengetahui persamaan regresi antara Lingkungan Kerja (X1) dan Kepemimpinan (X2) dengan KinerjacPetani (Y), maka dapat dilihat pada tabel di bawah ini:

Tabel 18. Anova uji signifikansi dan linearitas Regritas $\left(\mathrm{X}_{1}\right),\left(\mathrm{X}_{2}\right)$ dan $(\mathrm{Y})$

\begin{tabular}{llrrrrc}
\multicolumn{7}{c}{ ANOVA(b) } \\
\hline Model & Sum of Squares & df & Mean Square & F & Sig. \\
\hline 1 & Regression & .092 & 2 & .046 & 8.505 & $.000(\mathrm{a})$ \\
& Residual & 1.904 & 21 & .091 & & \\
\cline { 2 - 6 } & Total & 1.996 & 23 & & & \\
\hline
\end{tabular}

a. Predictors: (Constant), X1, X1

b. Dependent Variable: Y

Berdasarkan diatas terlihat bahwa Sig.F $(0,000)<0,05$ atau nilai Fhitung (8.505) $>2$, maka persamaan regresi dapat dikatakan sangat signifikan. Apabila disimpulkan berdasarkan persamaan regresi $=0,561+0,305 \mathrm{X} 1$ + 0,480X2, maka dapat diartikan bahwa setiap kenaikan 1 unit skor Lingkungan Kerja akan menyebabkan kinerja sebesar 0,305 pada konstanta 0,561 dan juga Kepemimpinan akan menyebabkan kenaikan skor Kinerja Petani sebesar 0,480 pada konstanta 0,561.

\section{Analisis Jalur}

Berdasarkan hasil analisis di atas, maka analisis jalur dapat digambarkan sebagai berikut : 


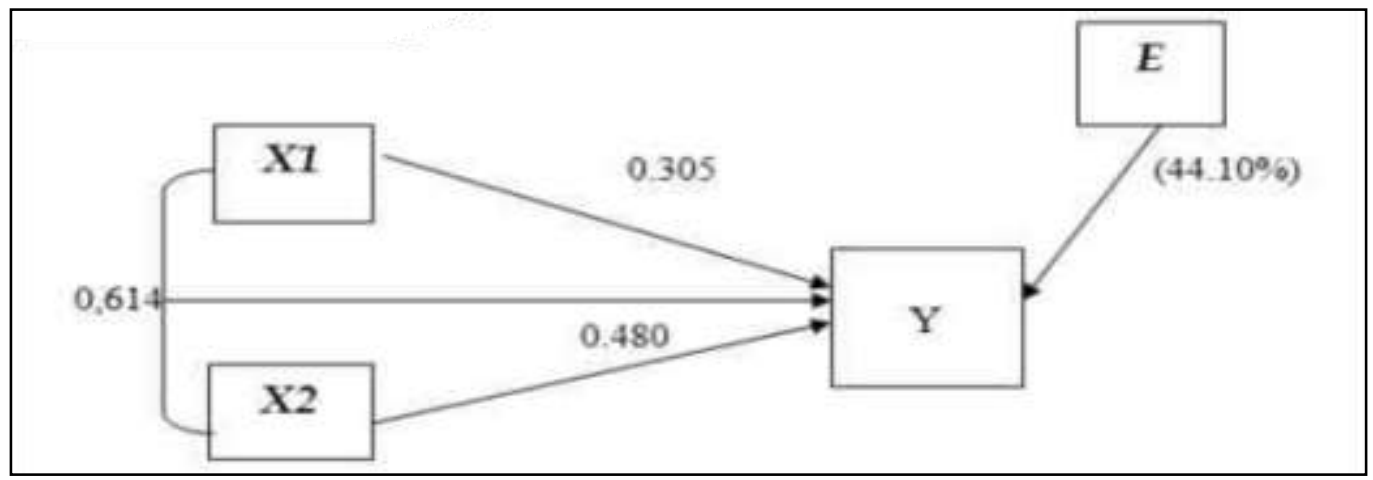

Gambar 1. Analsis jalur.

Berdasarkan table di atas, ternyata hubungan lingkungan kerja dan kepemimpinan secara simultan terhadap kinerja Petani sebesar 0,614 atau memberikan kontribusi (determinasi) sebesar $45.90 \%$, sehingga terdapat variabel lain yang mempengaruhi kinerja Petani selain lingkungan kerja dan kepemimpinan sebesar $44.10 \%$ atau 0,386 (koefisien standardize).

Hasil analisis diatas dapat ditulis dalam persamaan regresi, yaitu:

$\mathrm{Y}=0.614+0.305 \mathrm{X} 1+0.480 \mathrm{X} 2$

Persamaan regresi tersebut mempunyai arti:

a. Jika Lingkungan Kerja (X1) naik satu maka kinerja Petani (Y) akan naik 0.305 , tetapi dengan asumsi yang lain dianggap tetap, dan signifikan pada $\alpha$ $<0.05$.

b. Jika Kepemimpinan (X2) naik satu maka kinerja Petani (Y) akan naik 0.480 , tetapi dengan asumsi yang lain dianggap tetap, dan signifikan pada $\alpha$ $<0.05$.

c. Jika Lingkungan Kerja (X1) dan Kepemimpinan (X2) naik satu maka Kinerja Petani (Y) akan naik 0.614 dan signifikan pada $\mathrm{F}<0.05$.

\section{Uji Instrumen Reliabilitas}

1) Menguji reliabilitas variable (X1), lingkungan kerja, dapat dianalisis melalui program komputer statistik SPSS maka diperoleh nilai alpha crobach sebesar 0.7459 nilai ini lebih dari 0.6 yang artinya variabel reliabel yang juga artinya, bahwa jawaban responden konsisten

2) Menguji reliabilitas variable (X2) kepemimpinan, dapat dianalisis melalui program komputer statistik SPSS maka diperoleh nilai alpha crobach sebesar 0.7080 nilai ini lebih dari 0.6 yang artinya variabel reliabel yang juga artinya, bahwa jawaban responden konsisten.

3) Menguji reliabilitas variable $(Y)$ kinerja Petani, dapat dianalisis melalui program komputer statistik SPSS maka diperoleh nilai alpha crobach sebesar 0.6878 nilai ini lebih dari 0.6 yang artinya variabel reliabel yang juga artinya, bahwa jawaban responden konsisten.

\section{Uji instrument Validitas}

1) Uji Validitas lingkungan kerja (X1) dilakukan terhadap 10 Indikator yang dapat dilihat dalam tabel hasil perhitungan komputer program SPSS analisis pearson correlation di bawah ini. 
Tabel 19. Validitas variable lingkungan kerja $\left(\mathrm{X}_{1}\right)$

\begin{tabular}{cccc}
\hline Butir pertanyaan & r dengan total & Nilai kritis & Keterangan \\
\hline 1 & 0.572 & 0.3 & Valid \\
2 & 0,606 & 0.3 & Valid \\
3 & 0.510 & 0.3 & Valid \\
4 & 0.322 & 0.3 & Valid \\
5 & 0.383 & 0.3 & Valid \\
6 & 0.497 & 0.3 & Valid \\
7 & 0.315 & 0.3 & Valid \\
8 & 0.350 & 0.3 & Valid \\
9 & 0.410 & 0.3 & Valid \\
10 & 0.373 & 0.3 & Valid \\
\hline
\end{tabular}

Nilai kritis $\mathrm{r}$ diambil dari Tabel nilai kritis $\mathrm{r}$ pada $\mathrm{n}=24$ dan $\alpha=0.05$.

2) Uji Validitas kepemimpinan $\left(X_{2}\right)$ terhadap 10 Indikator yang dapat komputer program SPSS analisis dilihat dalam tabel hasil perhitungan pearson correlation di bawah ini :

Tabel 20. Validitas variable kepemimpinan $\left(\mathrm{X}_{2}\right)$.

\begin{tabular}{cccc}
\hline Butir pertanyaan & r dengan total & Nilai kritis & Keterangan \\
\hline 1 & 0.439 & 0.3 & Valid \\
2 & 0,722 & 0.3 & Valid \\
3 & 0.494 & 0.3 & Valid \\
4 & 0.685 & 0.3 & Valid \\
5 & 0.453 & 0.3 & Valid \\
6 & 0.717 & 0.3 & Valid \\
7 & 0.420 & 0.3 & Valid \\
8 & 0.495 & 0.3 & Valid \\
9 & 0.384 & 0.3 & Valid \\
10 & 0.397 & 0.3 & Valid \\
\hline
\end{tabular}

Nilai kritis $\mathrm{r}$ diambil dari Tabel nilai kritis $\mathrm{r}$ pada $\mathrm{n}=24$ dan $\alpha=0.05$.

3) Uji Validitas kinerja Petani (Y) perhitungan komputer program terhadap 8 Indikator yang dapat SPSS analisis pearson correlation di dilihat dalam tabel hasil bawahini:

Tabel 21. Validasi variable kinerja pegawai Y.

\begin{tabular}{cccc}
\hline Butir pertanyaan & r dengan total & Nilai kritis & Keterangan \\
\hline 1 & 0.329 & 0.3 & Valid \\
2 & 0,369 & 0.3 & Valid \\
3 & 0.501 & 0.3 & Valid \\
4 & 0.500 & 0.3 & Valid \\
5 & 0.371 & 0.3 & Valid \\
6 & 0.573 & 0.3 & Valid \\
7 & 0.642 & 0.3 & Valid \\
8 & 0.448 & 0.3 & Valid \\
\hline
\end{tabular}

Nilai kritis r diambil dari Tabel nilai kritis $\mathrm{r}$ pada $\mathrm{n}=24$ dan $\alpha=0.05$. 


\section{KESIMPULAN}

1. Pengaruh lingkungan kerja (X1) terhadap kinerja Petani (Y) ditunjukkan oleh nilai korelasi X1 dengan $\mathrm{Y}$ sebesar $\mathrm{r}=0.305$, artinya pengaruh antara lingkungan kerja ( $X$ 1) dengan kinerja pegawai mempunyai hubungan yang cukup, dan sifat hubungannyam+ (positif) artinya semakinnmeningkat lingkungan kerja (X1) maka semakin meningkat kinerja Petani $(\mathrm{Y})$.

2. Pengaruh Kepemimpinan (X2) dengan kinerja Petani $(\mathrm{Y})$ ditunjukan oleh nilai korelasi X2 dengan $\mathrm{Y}$ sebesar $\mathrm{r}=0.480$, artinya pengaruh kepemimpinan (X2) dengan kinerja Petani (Y) mempunyai hubungan cukup, dan sifat hubungannya + (positif) yang artinya semakin meningkat kepemimpinan (X2) maka semakin meningkat kinerja Petani (Y).

3. Pengaruh dari lingkungan kerja (X1) dan kepemimpinan (X2) terhadap kinerja Petani (Y) ditunjukan oleh nilai multiple korelasi, yang menunjukan nilai $\mathrm{r}=0.614$, dan besarnya pengaruh dari lingkungan kerja dan kepemimpinan Cahaya Agribiz Pagelaran Kabupaten Cianjur terhadap kinerja Petani sebesar $45.90 \%(\mathrm{r}$ square $=0.614)$, pernyataan ini mempunyai arti pengaruh lingkungan kerja (X1) dan kepemimpinan (X2) dengan kinerja Petani (Y) memiliki hubungan positif dan pengaruh yang cukup kuat. Dan sifat hubungannya positif yang artinya meningkatnya lingkungan kerja dan kepemimpinan Cahaya Agribiz Pagelaran Kabupaten Cianjur secara bersama-sama akan meningkatkan kinerja Petani .

\section{DAFTAR PUSTAKA}

A.Anwar Prabu Mangkunegara.2005. Manajemen Sumber Daya Manusia Perusabaan. Remaja Rosdakarya. Bandung.
Alex S. Nitisemito.2002. Manajemen Personalia. Cetakan Kesembilan. Edisi Ketiga. Jakarta: Penerbit Ghali Indonesia.

Ahmad Tohari. 2002. Manajemen Sumber Daya Manusi Bandung:Penerbit CV. Mandar Maju.

Gibson, 1999. Organisaasi . Jakarta: Jembatan.

Hadari Nawawi. 2001. Manajemen Sumber Daya Manusia Untuk. Bisnis yang Kompetitif, Cetakan Pertama.Yogyakarta: Penerbit UGM.

Husein Umar. 2002. Riset Sumber Daya Manusia Dalam Organisasi, Edisi Revisi \& Perluasan. Jakarta: Penerbit PT. Gramedia Pustaka Utama.

H.B. Siswanto .2006. Pengantar Manajemen. Jakarta: Penerbit Bumi Aksara

I Gusti Ngurah Gorda.2006.Kenneth N. Wexley dan Gary A. Yuki. 2003. Perilaku Organisasi dan Psikologi Personalia. Jakarta:. Penerbit Rineka Cipta.

Malayu Hasibuan.2004.Manajemen Sumber Daya Manusia. Edisi revisi. Bumi Aksara. Jakarta.

Miftah Thoha,2003. Kepemimpinan Dalam Manajemen Suatu Pendekatan Perilaku. Cetakan Kesembilan. Jakarta: Penerbit PT. Raja Grafindo Persada.

Moekijat 2002. Manajemen Sumber Daya Manusia (Manajemen Ke Petani an), Jakarta: Penerbit Mandar Maju.

Supardi dan Syaiful Anwar. 2002. Dasardasar Perilaku Organisasi. Yogyakarta: Penerbit UII Press.

Soedibjo,S.Bambang. 2005. Pengantar Metode Penelitian. Jurusan Manajemen STIE PASIM Bandung.

Sarah Cook.1999. How To Improve your Customer Service. Jakarta: Gramedia

Sugiyono. 2004. Metode Penelitian Bisnis. Bandung: Penerbit Alfabeta.

Sondang P. Siagian. 2002. Manajemen Sumber Daya Manusia. Jakarta: Penerbit Bumi Aksara. 